\title{
INFLUENCE OF POLYSACCHARIDE-PROTEIN COMPLEX ON THE EFFICIENCY OF BACTERIZATION OF SOYBEAN WITH RYZOHUMIN
}

\author{
S. F. Kozar, T. A. Yevtushenko, T. O. Usmanova \\ Institute of Agricultural Microbiology and Agroindustrial Manufacture, NAAS \\ 97 Shevchenka str., Chernihiv, 14035; Ukraine; e-mail: kozarsf@gmail.com
}

Objective. Study the effect of the polysaccharide-protein complex on the efficiency of the use of the microbial preparation Ryzohumin for presowing and early bacterization of soybean seeds. Methods. Field experiment, microbiological, gas chromatography, mathematical statistics methods. Results. The influence of presowing bacterization of Suziria soybean variety on the formation of plant-microbial symbiosis with the use of Ryzohumin and simultaneous treatment of seeds with polysaccharide-protein complex (PPC) was studied. It was found that the highest number of nodules was in the variant with presowing bacterization using Ryzohumin with PPC: 4.5 times higher compared to control. In the variant with the use of PPC with early bacterization of seeds, the number of nodules on the roots of the plants was at the level of the variant with presowing bacterization using Ryzohumin (without PPC), although it was lower than the variant with presowing bacterization with the use of PPC. The largest weight of nodules was found during presowing bacterization using Ryzohumin and PPC treatment: it was on average 5.3 times higher compared to control during the years of studies. In the study of the influence of bacterization on the nitrogen-fixing activity of soybean nodule bacteria, its growth in all variants with bacterization was established. The highest activity was observed in the variant with presowing bacterization and treatment using PPC $6,278.0 \mathrm{nmol} \mathrm{C}_{2} \mathrm{H}_{4} /$ plant per hour, which is 2.7 times higher in comparison with the control parameters (without bacterization). With the early bacterization of seeds with Ryzohumin and PPC, the activity of nitrogen fixation was at the level of the variant with pre-sowing bacterization without PPC. On average, over the three years, the yield of soybean under pre-sowing bacterization was 3.33-3.43 t/ha, which is 29.6-33.5\% higher than in the control, and early bacterization with Ryzohumin and PPC treatment provided an increase of $0.68 \mathrm{t} / \mathrm{ha}$, which is $26.5 \%$ higher than in the control. Conclusion. Bacterization with Ryzohumin and simultaneous treatment with PPC helps to increase the weight and number of nodules on the roots of soybean plants both during pre-sowing and early bacterization of seeds. Formation of effective plant-microbial symbiosis provides an increased yield of soybeans up to $33.5 \%$ compared to the control variant. At the same time, early bacterization simultaneously with PPC provides an increased yield of $26.5 \%$. The data obtained can be used to improve soybean cultivation technologies.

Key words: nodule bacteria, nitrogen-fixing activity, Ryzohumin, polysaccharide-protein complex, soybean.

Introduction. Specific symbiotic nitrogenfixing bacteria, developing in the root zone of legumes, can improve their nutrition and stimulate growth and development. The problem is that as a result of a number of predominantly abiotic factors, diazotrophs lose their viability, which should be taken into account when using microbial preparations that are intended to im- prove the productivity of leguminous crops, in particular, soybeans. Particularly critical is the death of bacterial cells of biological agents of biopreparations in the period from seed inoculation to the beginning of development of the root system of the plant, which results in decreased efficiency of inoculation. This problem can be solved by increasing the viability of the micro- 
organisms on the seeds by using certain substances.

Analysis of recent studies and publications. Maintenance of bacterial viability can be influenced by substances of different origin: sucrose, maltose [1], glycerol [2; 3], sodium alginate $[4 ; 5]$, gum arabic $[6 ; 7]$, polyvinyl pyrrolidone [1]. There is an evidence of a positive effect of organic film-forming due to the protective effect on the viability of rhizobia upon inoculation of soybean seeds. The preparation containing this film-forming agent makes it possible to increase the period between seed treatment and sowing to 30 days, while maintaining the nodulation activity of bacteria [8]. It has been shown that the storage of nodule bacteria in a vermiculite-based filler with the addition of Darina (a complex sapropel-based product with addition of nutrients and trace elements), molasses, potassium humates, glycerol, glucose, potassium sorbate, carboxymethylcellulose in different concentrations and ratios allows improvement in viability of studied microorganisms and gain increase of the yield [9].

Other authors have evaluated the influence of polyvinyl pyrrolidone, polyethylene glycol, polyvinyl alcohol, gum arabic, starch and sodium alginate on the maintenance of rhizobia in liquid medium and on seeds. Supplements have been shown to promote the survival of microorganisms. In this case, cell viability depended on the strain of bacteria and chemicals being tested [10].

It is noted that preference should be given to substances of a polymeric nature, which most effectively protect nitrogen-fixing bacteria from the negative impact of stressors [11]. Experiments with inoculation of seeds by soybean nodule bacteria showed that cells of these diazotrophs survive better with simultaneous inoculation using polyacrylamide gel [12].

In previous studies, we have shown that a polysaccharide-protein complex that has a positive effect on the survival of diazotrophs, in particular, soybean nodule bacteria, is promising for increasing the viability of soybean nodule bacteria [13].

Study objective - to study the influence of the polysaccharide-protein complex on the efficiency of the use of the microbial preparation Ryzohumin for pre-sowing and early bacterization of soybean seeds.

Materials and methods. Field experiments were carried out on meadow-chernozem leached loamy soil (humus content (according to Tiuryn) $-3.1 \%$, total nitrogen $-0.27 \%$, water-soluble $\mathrm{P}_{2} \mathrm{O}_{5}$ (according to Kirsanov) $15 \mathrm{mg} / 100 \mathrm{~g}$ of soil, exchangeable $\mathrm{K}_{2} \mathrm{O}$ (according to Maslova) $-16 \mathrm{mg} / 100 \mathrm{~g}, \mathrm{pH}=6.1$ ) of the experimental field of the Institute of Agricultural Microbiology and Agroindustrial Manufacture of the NAAS.

The scheme of the experiment to study the influence of soybean bacterization with Ryzohumin and treatment with polysaccharideprotein complex (PPC) on the growth and development of soybean plants provided the following variants:

1. Control (without treatment).

2. Treatment of seeds with PPC.

3. Presowing bacterization with Ryzohu$\min$

4. Presowing bacterization with Ryzohumin + PPC treatment.

5. Bacterization with Ryzohumin (1 month in advance).

6. Bacterization with Ryzohumin + PPC treatment (1 month in advance).

The area of the accounting plot is $10 \mathrm{~m}^{2}$. Repeatability is 4-fold.

Suziria soybean variety. Originator $-\mathrm{Na}-$ tional Scientific Center "Institute of Agriculture of the NAAS". Soybean variety with determinant type of growth, registered in the Register of varieties of Ukraine in 2010. Recommended growing areas: Polissia, Forest-Steppe and Steppe zones of Ukraine.

Microbial preparation Ryzohumin (TU U 24.1-00497360-003:2007, Certificate of State Registration A 01863), as well as PPC (based on sodium alginate, starch and gelatine) were used for the presowing treatment of soybean seeds in experiments [13].

The determination of the activity of nitrogen fixation in root nodules was performed by acetylene method $[14 ; 15]$ on a Chrom 4 gas chromatograph with a flame ionization detector. The sorption steel columns were filled with Porapak Q 60-80 mesh sorbent. The thermostat temperature was $40^{\circ} \mathrm{C}$. Gas consumption: hydrogen $-15 \mathrm{~cm}^{3} / \mathrm{min}$, nitrogen $-100 \mathrm{~cm}^{3} / \mathrm{min}$, air $-500 \mathrm{~cm}^{3} / \mathrm{min}$.

Planning and conducting field experiments, crop accounting and statistical processing of the obtained data were performed according to existing methods [16;17]. The resulting digital 
material was processed by the method of analysis of variance using the Excel software package.

Results. During the study of the influence of presowing bacterization of soybean seeds on the formation of nitrogen-fixing symbiosis, it was found that in the average of three years, the highest number of nodules was in the variant with presowing bacterization with Ryzohumin together with PPC treatment: parameters are 4.5 times higher compared with the control (Table 1). When Ryzohumin was used early and without PPC, the number of nodules was lower in terms of variants with and without presowing bacterization of seeds with this microbial preparation and $\mathrm{PPC}$.

It was found that in the variant with the use of PPC and early bacterization of seeds, the number of nodules on the roots of the plants was at the level of parameters of the variant using presowing bacterization withal Ryzohumin (without PPC), although it was lower than the variant using presowing bacterization and simultaneous PPC treatment.

The largest weight of nodules was detected during presowing bacterization with Ryzohumin and treatment with PPC: on average, it was 5.3 times higher in control over the years. In the variant with early bacterization of seeds without PPC, the weight of the nodules was almost twice lower in comparison with the early bacterization with PPC (Table 2). In the variant with only PPC treatment (without seed bacteriza- tion), an increase in both the number and weight of the nodules on the roots of soybean plants was found, which can be explained by the positive influence of the polysaccharide-protein complex on the development of native nodule bacteria.

In the study of the effect of bacterization on the nitrogen-fixing activity of soybean nodule bacteria under symbiosis conditions, its growth in all variants with the microbial preparation Ryzohumin was established (Table 3 ). The traditional presowing treatment of seeds with only a microbial preparation provided 2.4-fold increase of parameters compared with control (without bacterization) in the soybean flowering phase over an average of three years. The highest activity was in the variant with presowing bacterization simultaneously with PPC treatment, and amounted to $6,278.0 \mathrm{nmol}_{2} \mathrm{H}_{4} /$ plant per hour, which is 2.7 times higher than in the control. In case of early bacterization without PPC, nitrogen-fixing activity was the lowest among the variants with Ryzohumin, but it was higher in comparison with the control by $57.6 \%$. During early bacterization of seeds with Ryzohumin simultaneously with PPC treatment, nitrogen-fixing activity was at the level of the variant with presowing bacterization without PPC treatment: $5,063.6 \mathrm{nmol} \mathrm{C}_{2} \mathrm{H}_{4} /$ plant per hour, which is $115.5 \%$ higher than in the control and $36.7 \%$ higher than in the variant with early bacterization without PPC. The obtained data can be explained by the ability of PPC to

Table 1. Influence of inoculation of soybean seeds on the number of nodules on the root, flowering phase (2017-2019)

\begin{tabular}{|l|c|c|c|c|c|c|}
\hline \multirow{2}{*}{ Variants of experiment } & \multicolumn{3}{|c|}{ Number of nodules, pcs/plant } & \multicolumn{2}{c|}{ \pm to control } \\
\cline { 2 - 7 } & 2017 & 2018 & 2019 & Mean & pcs/plant & $\%$ \\
\hline Control (without treatment) & $5.0 \pm 0.9$ & $35.3 \pm 4.1$ & $21.7 \pm 2.0$ & 20.7 & - & - \\
\hline Treatment with PPC & $7.3 \pm 1.8$ & $54.7 \pm 6.5$ & $26.0 \pm 4.9$ & 29.3 & +8.6 & +41.5 \\
\hline $\begin{array}{l}\text { Presowing bacterization with } \\
\text { Ryzohumin }\end{array}$ & $15.7 \pm 2.0$ & $91.0 \pm 9.6$ & $54.3 \pm 5.8$ & 53.7 & +33.0 & +159.4 \\
\hline $\begin{array}{l}\text { Presowing bacterization } \\
\text { with Ryzohumin and PPC } \\
\text { treatment }\end{array}$ & $17.7 \pm 2.2$ & $169.3 \pm 17.9$ & $92.7 \pm 6.4$ & 93.2 & +72.5 & +350.2 \\
\hline $\begin{array}{l}\text { Bacterization with Ryzo- } \\
\text { humin (1 month in advance) }\end{array}$ & $12.0 \pm 1.7$ & $80.7 \pm 5.0$ & $46.7 \pm 2.4$ & 46.5 & +25.8 & +124.6 \\
\hline $\begin{array}{l}\text { Bacterization with Ryzo- } \\
\text { humin and PPC treatment } \\
(1 \text { month in advance) }\end{array}$ & $15.7 \pm 2.8$ & $92.3 \pm 5.6$ & $55.7 \pm 5.2$ & 54.7 & +34.0 & +164.3 \\
\hline
\end{tabular}


Table 2. Influence of presowing inoculation of soybean seeds of Suziria variety on nodule weight, flowering phase (2017-2019)

\begin{tabular}{|l|c|c|c|c|c|c|}
\hline \multirow{2}{*}{ Variants of experiment } & \multicolumn{4}{|c|}{ Number of nodules, pcs/plant } & \multicolumn{2}{c|}{ \pm to control } \\
\cline { 2 - 7 } & 2017 & 2018 & 2019 & Mean & pcs/plant & $\%$ \\
\hline Control (without treatment) & $0.09 \pm 0.01$ & $0.16 \pm 0.04$ & $0.11 \pm 0.02$ & 0.12 & - & - \\
\hline Treatment with PPC & $0.17 \pm 0.01$ & $0.24 \pm 0.05$ & $0.22 \pm 0.04$ & 0.21 & +0.09 & +75.0 \\
\hline $\begin{array}{l}\text { Presowing bacterization with } \\
\text { Ryzohumin }\end{array}$ & $0.52 \pm 0.05$ & $0.64 \pm 0.12$ & $0.62 \pm 0.07$ & 0.59 & +0.47 & +391.7 \\
\hline $\begin{array}{l}\text { Presowing bacterization } \\
\text { with Ryzohumin and PPC } \\
\text { treatment }\end{array}$ & $0.55 \pm 0.04$ & $0.50 \pm 0.08$ & $0.83 \pm 0.03$ & 0.63 & +0.51 & +425.0 \\
\hline $\begin{array}{l}\text { Bacterization with Ryzo- } \\
\text { humin (1 month in advance) }\end{array}$ & $0.22 \pm 0.03$ & $0.24 \pm 0.05$ & $0.37 \pm 0.02$ & 0.28 & +0.14 & +133.3 \\
\hline $\begin{array}{l}\text { Bacterization with Ryzo- } \\
\text { humin and PPC treatment } \\
(1 \text { month in advance) }\end{array}$ & $0.39 \pm 0.01$ & $0.53 \pm 0.09$ & $0.58 \pm 0.04$ & 0.50 & +0.38 & +316.7 \\
\hline
\end{tabular}

Table 3. Influence of inoculation of soybean plants on nitrogen-fixing activity, flowering phase (field experiment 2017-2019)

\begin{tabular}{|c|c|c|c|c|c|c|}
\hline \multirow{2}{*}{$\begin{array}{l}\text { Variants of } \\
\text { experiment }\end{array}$} & \multicolumn{4}{|c|}{$\begin{array}{l}\text { Nitrogen-fixing activity, } \\
\text { nmol } \mathrm{C}_{2} \mathrm{H}_{4} / \text { plant per hour }\end{array}$} & \multicolumn{2}{|c|}{ \pm to control } \\
\hline & 2017 & 2018 & 2019 & Mean & $\begin{array}{c}\text { nmol } \mathrm{C}_{2} \mathrm{H}_{4} / \\
\text { plant per hour }\end{array}$ & $\%$ \\
\hline $\begin{array}{l}\text { Control } \\
\text { (without treatment) }\end{array}$ & $\begin{array}{l}2,603.0 \\
\pm 433.0\end{array}$ & $\begin{array}{l}2,103.0 \\
\pm 33.0\end{array}$ & $\begin{array}{l}2,343.3 \\
\pm 156.0\end{array}$ & $2,349.8$ & - & - \\
\hline Treatment with PPC & $\begin{array}{l}3,208.3 \\
\pm 100.1\end{array}$ & $\begin{array}{l}2,528.3 \\
\pm 112.3\end{array}$ & $\begin{array}{l}2,834.0 \\
\pm 370.9\end{array}$ & $2,856.9$ & +507.1 & +21.6 \\
\hline $\begin{array}{l}\text { Presowing bacterization with } \\
\text { Ryzohumin }\end{array}$ & $\begin{array}{l}6,101.6 \\
\pm 169.5 \\
\end{array}$ & $\begin{array}{l}5,041.6 \\
\pm 201.5 \\
\end{array}$ & $\begin{array}{l}5,634.3 \\
\pm 462.8 \\
\end{array}$ & $5,592.5$ & $+3,242.7$ & +138.0 \\
\hline $\begin{array}{l}\text { Presowing bacterization with } \\
\text { Ryzohumin and PPC treat- } \\
\text { ment }\end{array}$ & $\begin{array}{l}6,533.3 \\
\pm 162.2\end{array}$ & $\begin{array}{l}6,013.3 \\
\pm 105.3\end{array}$ & $\begin{array}{l}6,287.3 \\
\pm 418.8\end{array}$ & $6,278.0$ & $+3,928.2$ & +167.2 \\
\hline $\begin{array}{l}\text { Bacterization with Ryzo- } \\
\text { humin ( } 1 \text { month in advance) }\end{array}$ & $\begin{array}{l}4,161.8 \\
\pm 256.1\end{array}$ & $\begin{array}{l}3,294.1 \\
\pm 162.3\end{array}$ & $\begin{array}{l}3,656.0 \\
\pm 380.7\end{array}$ & $3,704.0$ & $+1,354.2$ & +57.6 \\
\hline $\begin{array}{l}\text { Bacterization with Ryzo- } \\
\text { humin and PPC treatment ( } 1 \\
\text { month in advance) }\end{array}$ & $\begin{array}{l}4,794.1 \\
\pm 362.3\end{array}$ & $\begin{array}{l}4,981.8 \\
\pm 206.8\end{array}$ & $\begin{array}{l}5,415.0 \\
\pm 472.6\end{array}$ & $5,063.6$ & $+2,713.8$ & +115.5 \\
\hline
\end{tabular}

increase the viability of soybean nodule bacteria, which had a positive effect on the efficiency of plant-microbial symbiosis.

The integral parameter that determines the efficiency of a particular practice is the yield of crops. Soybean productivity studies under presowing seed treatment with Ryzohumin have shown high efficiency in agricultural practice. On average, over the three years, the yield of soybean under presowing bacterization was
$3.33-3.43 \mathrm{t} / \mathrm{ha}$, which is $29.6-33.5 \%$ higher than the control parameters, and early bacterization with Ryzohumin and PPC treatment provided an increase of $0.68 \mathrm{t} / \mathrm{ha}$, which is $26.5 \%$ higher than in the control (Table 4).

Thus, bacterization with Ryzohumin and simultaneous treatment with PPC helps to increase the weight and number of nodules on the roots of soybean plants both under presowing and early bacterization of seeds. Formation of 
Table 4. Influence of presowing bacterization on the yield of soybean grain of Suziria variety (field experiment 2017-2019)

\begin{tabular}{|l|c|c|c|c|c|c|}
\hline \multirow{2}{*}{\multicolumn{1}{|c|}{ Variants of experiment }} & \multicolumn{5}{c|}{ Yield, t/ha } & \multicolumn{2}{c|}{ Yield increase } \\
\cline { 2 - 8 } & 2017 & 2018 & 2019 & Mean & t/ha & $\%$ \\
\hline Control (without treatment) & 2.07 & 3.07 & 2.57 & 2.57 & - & - \\
\hline Treatment with PPC & 2.11 & 3.23 & 2.73 & 2.69 & 0,12 & 4,7 \\
\hline $\begin{array}{l}\text { Presowing bacterization with } \\
\text { Ryzohumin }\end{array}$ & 2.55 & 4.23 & 3.20 & 3.33 & 0,76 & 29,6 \\
\hline $\begin{array}{l}\text { Presowing bacterization with } \\
\text { Ryzohumin and PPC treatment }\end{array}$ & 2.82 & 4.12 & 3.34 & 3.43 & 0,86 & 33,5 \\
\hline $\begin{array}{l}\text { Bacterization with Ryzohumin } \\
(1 \text { month in advance) }\end{array}$ & 2.25 & 3.67 & 2.78 & 2.90 & 0,33 & 12,8 \\
\hline $\begin{array}{l}\text { Bacterization with Ryzohumin and } \\
\text { PPC treatment (1 month in advance) }\end{array}$ & 2.50 & 4.10 & 3.16 & 3.25 & 0,68 & 26,5 \\
\hline $\mathrm{HIP}_{05}$ & 0.20 & 0.33 & 0.27 & & & \\
\hline
\end{tabular}

effective plant-microbial symbiosis provides a yield increase of soybeans up to $33.5 \%$ compared to the control variant. At the same time, early bacterization in combination with PPC provides a yield increase of $26.5 \%$.

\section{REFERENCES}

1. Bushby, H. V. A., \& Marshall C. (1977). Some factors affecting the survival of root-nodule bacteria on desiccation. Soil biology and biochemistry, 9(3), 143-147.

2. Bekker, M. E., Damberh, B. E., \& Rapoport, A. Y. (1981). Anabyoz mykroorhanyzmov [Microorganism Anabiosis]. Ryha : Zyatne [in Russian].

3. Kalakutskyi, L. V., \& Sydiakyna, T. M. (1988). Anabyoz y konservatsyia mykroorhanyzmov [Anabiosis and preservation of microorganisms]. Kryobyolohyia - Cryobiology, 4, 3-9 [in Russian].

4. Bashan, Y., Hernandez, J. P., Leyva, L. A., \& Bacilio, M. (2002). Alginate microbeads as inoculant carriers for plant growth promoting bacteria. Biology and fertility of soils, 35, 359-368.

5. Bashan, Y., \& Gonzalez, L. E. (1999). Longterm survival of the plant-growth-promoting bacteria Azospirillum brasilense and Pseudomonas fluorescens in dry alginate inoculant. Applied microbiology and biotechnology, 51 (2), 262-266.

6. Temprano, F. J., Albareda, M., Camacho, M., Daza, A., Santamaría, C., \& Rodríguez-Navarro, D. N. (2002). Survival of several Rhizobium/ Bradyrhizobium strains on different inoculant formulations and inoculated seeds. International microbiology, 5(2), 81-86. https://doi.org/10.1007/ s10123-002-0067-y

7. Mugnier, J., \& Jung, G. (1985). Survival of bacteria and fungi in relation to water activity and the solvent properties of water in biopolymer. $A p$ plied and environmental microbiology, 50, 108-114.

8. Hryshechkyn, V. V., \& Holovyna, E. V. (2014). Yspolzovanye novoho orhanycheskoho plenkoobrazovatelia (PPO) dlia sokhranenyia zhyznesposobnosty ryzobyi pry ynokuliatsyy semian soy y vlyianye ykh na klubenkoobrazovanye y urozhainost [The use of a new organic film former (PPO) to maintain the viability of rhizobia during inoculation of soybean seeds and their effect on nodulation and productivity]. Nauchno-proyzvodstvennbli zhurnal "Zernobobovye y krupianye kultury" - Scientificproduction journal "Legumes and cereals", 1(9), 41-44 [in Russian].

9. Laktyonov, Yu. V., Popova, T. A., Andreev, O. A., Ybatullyna, R. P., \& Kozhemiakov, A. P. (2011). Sozdanye stabylnoi formy roststymulyruiushchykh mykrobyolohycheskykh preparatov y ykh effektyvnost [Creating a stable form of growthpromoting microbiological preparations and their effectiveness]. Selskokhoziaistvennaia byolohyia Agricultural biology, 3, 116-118 [in Russian].

10. Tittabutr, P., Payakapong, W., Teaumroong, N., Singleton, P. W., \& Boonkerd, N. (2007). Growth, survival and field performance of Bradyrhizobial liquid inoculant formulations with polymeric additives. Science Asia, 33. 69-77. https://doi.org/ 10.2306/scienceasia1513-1874.2007.33.069

11. Deaker R., Roughley R. J., \& Kennedy I. R. (2004). Legume seed inoculation technology - a review. Soil biology and biochemistry, 36(8), 12751288. https://doi.org/10.1016/j.soilbio.2004.04.009

12. Dommergues, Y. R., Diem, H. G., \& Divies, C. (1979). Polyacrylamide-entrapped Rhizobium as an inoculant for legumes. Applied and environmental microbiology, 37, 779-781. 
13. Kozar, S. F., Yevtushenko, T. A., \& Nesterenko, V. M. (2017). Vplyv rechovyn riznoho khimichnoho skladu na zhyttiezdatnist diazotrofiv na nasinni silskohospodarskykh kultur [An infusion of speeches of a diverse chemical warehouse for livelihood and entertainment for us of culture and culture]. Silskohospodarska mikrobiolohiia - Agricultural Microbiology, 25, 10-17 [in Ukrainian].

14. Hardy, R. W. F., Hotsren R. D., Jackson E. K., \& Burns R. C. (1968). The acetyleneethylene assay for $\mathrm{N}_{2}$ fixation: laboratory and field evaluation. Plant physiol, 43(8), 1185-1207.

15. Volkohon, V. V. (Ed.). (2010). Ekspery- mentalna gruntova mikrobiolohiia: monographia [Experimental soil microbiology: Monograph]. Kyiv : Ahrarna nauka [in Ukrainian].

16. Dospekhov, B. A. (1985). Metodyka polevoho opyta c osnovamy statystycheskoi obrabotky rezultatov yssledovanyi [Methods of field experience with basics of statistical processing of research results]. M. : Ahropromizdat [in Russian].

17. Ieshchenko, V. O., Kopytko, P. H., Kostohryz, P. V., \& Opryshko, V. P. (2014). Osnovy naukovykh doslidzhen $v$ ahronomii [Fundamentals of scientific research in agronomy]. Vinnytsia : Edelveis i $\mathrm{K}$ [in Ukrainian].

Received 30.07.2019

https://doi.org/10.35868/1997-3004.30.13-19

УДК 635.655:631.461

\title{
ВПЛИВ ПОЛІСАХАРИДНО-БІЛКОВОГО КОМПЛЕКСУ НА ЕФЕКТИВНІСТЬ БАКТЕРИЗАЦІЇ СОЇ РИЗОГУМІНОМ
}

\author{
С. Ф. Козар, Т. А. Свтушенко, Т. О. Усманова \\ Інститут сільськогосподарської мікробіології та агропромислового виробництва НААН, м. Чернігів \\ e-mail: kozarsf@gmail.com
}

Мета. Дослідити вплив полісахаридно-білкового комплексу на ефективність застосування мікробного препарату Ризогуміну за передпосівної $і$ завчасної бактеризачії насіння сої. Методи. Польового досліду, мікробіологічні, газохроматографічні, математичної статистики. Результати. Досліджено вплив передпосівної бактеризації сої сорту Сузір'я на утворення рослинно-мікробного симбіозу за використання Ризогуміну з одночасною обробкою насіння полісахаридно-білковим комплексом (ПБК). Виявлено, щзо найбільша кількість бульбочок була у варіанті з передпосівною бактеризаџією Ризогуміном з ПБК: у 4,5 рази вищца проти контролю. У варіанті з використанням ПБК за завчасної бактеризації насіння чисельність бульбочок на корінні рослин хоча й була нижчою проти варіанту з передпосівною бактеризацією з використанням ПБК, але перебувала на рівні варіанту з передпосівною бактеризачією Ризогуміном (без ПБК). Найбільшу масу бульбочок виявлено у варіанті з передпосівною бактеризацією Ризогуміном з обробкою ПБК: вона у середньому за роки досліджень була вищзою щзодо контролю у 5,3 раза. Під час дослідження впливу бактеризації на азотфіксувальну активність бульбочкових бактерій сої встановлено ї зростання у всіх варіантах з бактеризацією. Найвищу активність відмічено у варіанті з передпосівною бактеризацією та обробкою ПБК - 6278,0 нмоль $C_{2} H_{4} /$ рослину за годину, щуо у 2,7 раза вище щзодо показників контролю (без бактеризаиії). За завчасної бактеризаиії насіння Ризогуміном з обробкою ПБК активність азотфіксації була на рівні варіанту з передпосівною бактеризацією без ПБК. У середньому за три роки урожайність зерна сої за передпосівної бактеризачії становила 3,33-3,43 m/2a, щьо на 29,6-33,5\% вище до контролю, а завчасна бактеризачія Ризогуміном з обробкою ПБК забезпечила приріст 0,68 m/2a, щуо на 26,5\% вище контролю. Висновки. Бактеризачія Ризогуміном з одночасною обробкою ПБК сприяє збільшенню маси і кількості бульбочок на корінні рослин сої як за передпосівної, так $і$ за завчасної бактеризаџії насіння. Формування ефективного рослинно-мікробного симбіозу забезпечує приріст урожайності сої до 33,5 \% проти контрольного варіанту. Водночас завчасна 
бактеризація сумісно з ПБК забезпечує приріст урожаю на 26,5\%. Отримані дані можуть бути використані для удосконалення технологій вирощування сої.

Ключові слова: бульбочкові бактерії, азотфіксувальна активність, Ризогумін, полісахаридно-білковий комплекс, соя.

\section{ЦИТОВАНА ЛІТЕРАТУРА}

1. Bushby H. V. A., Marshall C. Some factors affecting the survival of root-nodule bacteria on desiccation. Soil biology and biochemistry. 1977. Vol. 9(3). P. 143-147.

2. Беккер М. Е., Дамберг Б. Э., Рапопорт А. И. Анабиоз микроорганизмов. Рига. Зиатне. $1981.252 \mathrm{c}$.

3. Калакуцкий Л. В., Сидякина Т. М. Анабиоз и консервация микроорганизмов. Криобиология. 1988. № 4. С. 3-9.

4. Bashan Y., Hernandez J. P., Leyva L. A., Bacilio M. Alginate microbeads as inoculant carriers for plant growth promoting bacteria. Biology and fertility of soils. 2002. Vol. 35. P. 359-368.

5. Bashan Y., Gonzalez L. E. Long-term survival of the plant-growth-promoting bacteria Azospirillum brasilense and Pseudomonas fluorescens in dry alginate inoculant. Applied microbiology and biotechnology. 1999. Vol. 51 (2). P. 262266.

6. Temprano F. J., Albareda M., Camacho M., Daza A., Santamaría C., Rodríguez-Navarro D. N. Survival of several Rhizobium/Bradyrhizobium strains on different inoculant formulations and inoculated seeds. International microbiology. 2002. Vol. 5 (2). P. 81-86. https://doi.org/10.1007/s10123002-0067-y

7. Mugnier J., Jung G. Survival of bacteria and fungi in relation to water activity and the solvent properties of water in biopolymer. Applied and environmental microbiology. 1985. Vol. 50. P. 108-114.

8. Гришечкин В. В., Головина Е. В. Использование нового органического пленкообразователя (ППО) для сохранения жизнеспособности ризобий при инокуляции семян сои и влияние их на клубенькообразование и урожайность. Научно-производственный журнал «Зернобобовые $и$ крупяные культуры». 2014. 1(9). С. 41-44.

9. Лактионов Ю. В., Попова Т. А., Андреев О. А., Ибатуллина Р. П., Кожемяков А. П. Со- здание стабильной формы ростстимулирующих микробиологических препаратов и их эффективность. Сельскохозяйственная биология. 2011. № 3. C. 116-118.

10. Tittabutr P., Payakapong W., Teaumroong N., Singleton P. W., Boonkerd N. Growth, survival and field performance of Bradyrhizobial liquid inoculant formulations with polymeric additives. Science Asia. 2007. Vol. 33. P. 69-77. https://doi.org/ 10.2306/scienceasia1513-1874.2007.33.069

11. Deaker R., Roughley R. J., Kennedy I. R. Legume seed inoculation technology - a review. Soil biology and biochemistry. 2004. Vol. 36(8). P. 1275-1288. https://doi.org/10.1016/j.soilbio.2004. 04.009

12. Dommergues Y. R., Diem H. G., Divies C. Polyacrylamide-entrapped Rhizobium as an inoculant for legumes. Applied and environmental microbiology. 1979. Vol. 37. P. 779-781.

13. Козар С. Ф., Свтушенко Т. А., Нестеренко В. М. Вплив речовин різного хімічного складу на життєздатність діазотрофів на насінні сільськогосподарських культур. Сільськогосподарська мікробіологія. 2017. Вип. 25. С. 10-17.

14. Hardy R. W. F., Hotsren R. D., Jackson E. K., Burns R. C. The acetylene-ethylene assay for $\mathrm{N}_{2}$ fixation: laboratory and field evaluation. Plant physiol. 1968. Vol. 43(8). P. 1185-1207.

15. Експериментальна грунтова мікробіологія : монографія / Волкогон В. В., Надкернична О. В., Токмакова Л. М. та ін.; за наук. ред. В. В. Волкогона. К. : Аграрна наука, 2010. 464 с.

16. Доспехов Б. А. Методика полевого опыта с основами статистической обработки результатов исследований. М. : Агропромиздат. 1985. $351 \mathrm{c}$.

17. Єщенко В. О., Копитко П. Г., Костогриз П. В., Опришко В. П. Основи наукових досліджень в агрономії. Вінниця : Едельвейс і К, 2014. $332 \mathrm{c}$. 